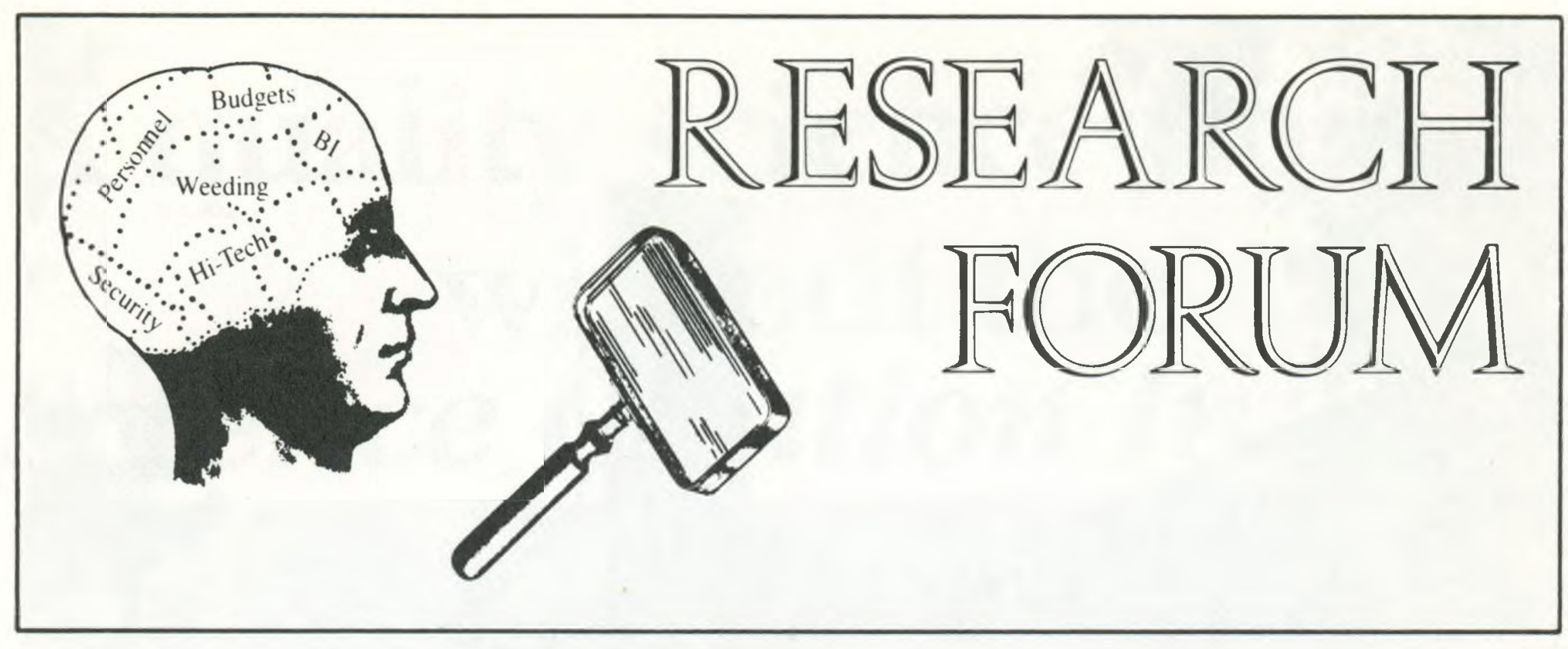

\title{
Research in a rotating librarian/faculty program
}

\author{
By Mary M. Huston \\ Member of the Faculty/Library \\ Evergreen State College
}

The library at Evergreen State College in Olympia, Washington, offers a unique opportunity for research and publication to the six librarians holding joint appointments in the library and on the faculty. Intense involvement in research occurs for one quarter every three years when we leave our library reference and administrative responsibilities to rotate into the teaching faculty (and a faculty member takes our place in the library). Research is encouraged by our participation in multidisciplinary teaching teams. Weekly faculty seminars encourage the sharing of individual research interests and guarantee collegial discussion on the common readings for faculty and students in the program. Faculty presentations to students in class are frequently elaborations of these research interests.

Here is an example of the way this academic structure stimulates research. When I was teaching in the Human Health and Behavior program in 1982-1983, I brought to the seminar my interest in the varying world-views and methodologies of different disciplines. The subject stimulated a lively debate on the implicit and explicit assumptions about the nature of reality which determine the development of knowledge as embodied in the literature of a subject. In the course of these deliberations, one of my colleagues introduced me to the sociology of knowledge field. Later I became sufficiently expert to present a contextual introduction for a collaboratively delivered presentation to students on the assumptions, contributions, and omissions of disciplinary literatures. Our classroom analyses of the research literatures extended and clarified for us our seminar discussions.

Continuing dialogue on the topic resulted a year and a half later in a manuscript on teaching infor- mation evaluation in bibliographic instruction, written by myself and the microbiologist on the team. We are also writing a paper on another aspect of the topic for presentation at a Canadian librarians' conference in the spring of 1985. A third spinoff of the seminar discussions and classroom presentation was a paper I presented at a Pacific Northwest writing conference on "Student Response and the Politics of Information."

In some cases then, we faculty librarians use our quarter of teaching to extend our familiarity with a topic. At other times-as I did with the sociology of knowledge literature-we develop new expertise through intensive research during the same quarter we are teaching. This occurs as an outgrowth of Evergreen's desire for faculty who are expert learners as well as expert teachers.

Our full-time opportunity for research is not limited to the quarters we rotate into the academic faculty to team teach. Regular participation in a program's faculty seminar is also required for faculty status. Collegial dialogue inevitably stimulates new research directions. Last year, for example, I was asked by my seminar colleagues to develop a lecture analyzing the reviews of Alice Walker's novel The Color Purple within the context of the political environment in which book reviewing occurs.

Having all the same privileges as the academic faculty, we are also eligible for professional leave. Next quarter I have been granted a leave to conduct research on methods for teaching students to recognize cultural bias in their formulation of social science research problems. My laboratory will be the classroom of a former seminar colleague.

The policy establishing faculty membership for 


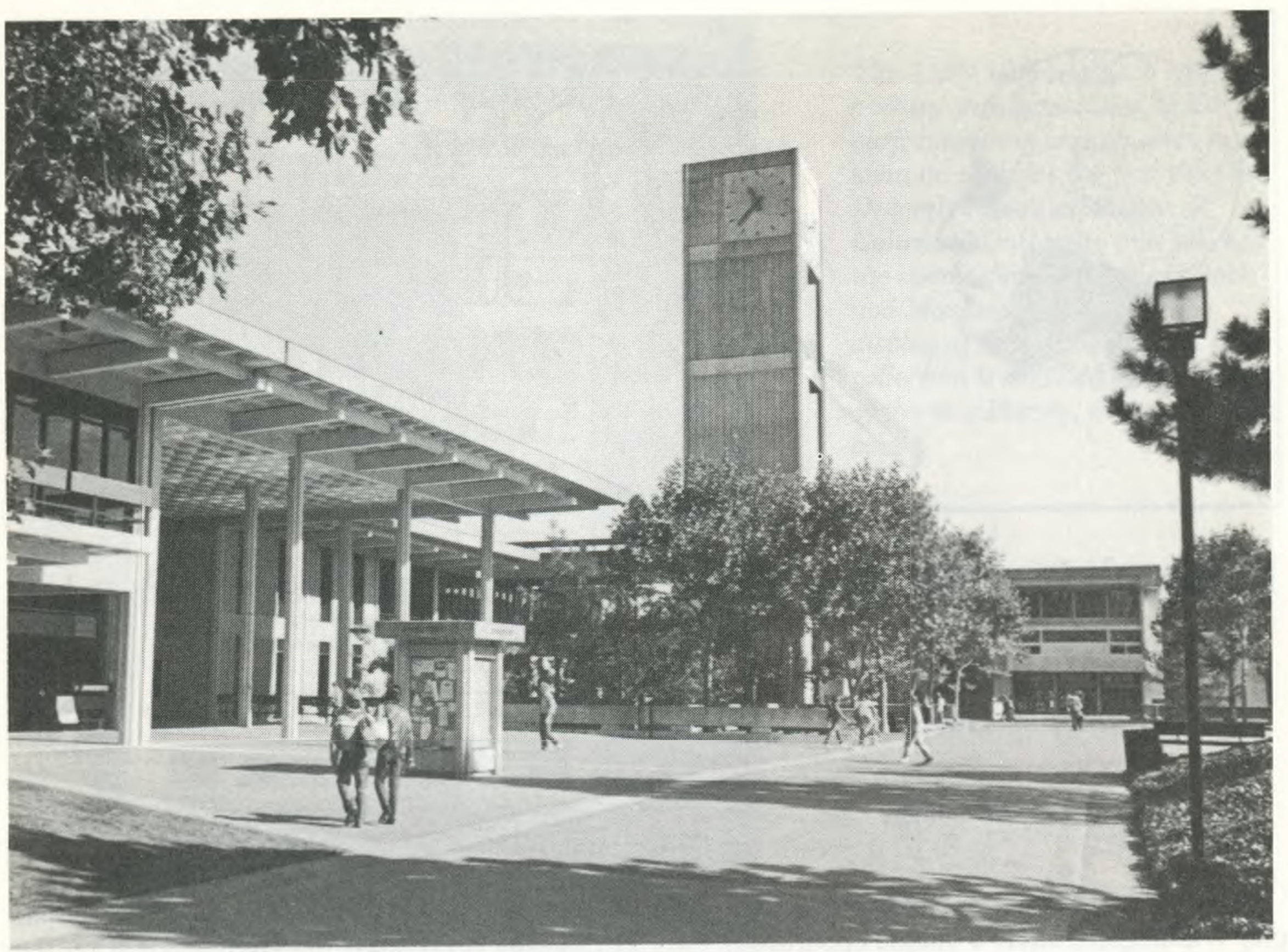

The Evergreen State College Library, Olympia, Washington.

Cr: Woody Hirzel

librarians was in the development stage for over four years from 1972 through 1976. Librarians and many of the academic faculty supported faculty membership for librarians from the time the college opened its doors in the fall of 1971. Some members of the academic faculty, however, questioned the addition of librarians into their ranks fearing it would dilute the intellectual quality of the faculty.

In the spring of 1973 the college president, under pressure from librarians to clarify his stand on the matter, stated that on an individual basis present and future members of the library staff may be screened for joint membership in the faculty and the library. Thus was born the idea of a faculty member rotating into the library to work as a librarian when a librarian rotated into full-time teaching.

The next three years involved innumerable meetings where the details of the policy were worked out, including whether the granting of faculty membership could be dependent on budget considerations or the availability of specific teaching positions at the college; whether faculty membership granted librarians automatic summer employment at the regular faculty pay scale; and whether the faculty librarian, if having failed as a teacher, could be retained as a non-faculty librarian. Three librarians out of five applied for faculty membership in March 1976. Their portfolios were reviewed by a faculty hiring committee and the first faculty librarian appointment was made in the spring of 1977.
Newly hired librarians now begin as either faculty librarians or administrative exempt librarians. Generally, librarians with significant bibliographic instruction duties are hired as faculty members, while librarians hired for more technical duties begin work as exempt staff. A librarian applying for a position as a faculty member at Evergreen is evaluated by both the research and teaching criteria applied to academic faculty appointments and the technical and bibliographic criteria applied to other librarian candidates.

Additional discussion of the rotation scheme is available in a paper by Mary M. Huston and Frank Motley, "Faculty Membership for Librarians: The Evergreen State College Model," in Michael D.

\section{Clarifications}

C. Lee Jones, author of "Issues in Retrospective Conversion" in the November 1984 issue of $C \& R L$ News, is with the Council for Library Resources as a consultant, and not an employee of the U.S. government as stated in the Editor's note.

Edward G. Holley will relinquish the deanship of the School of Library Science at the University of North Carolina at Chapel Hill on June 30,1985 , at which time he will return to full-time teaching. This corrects a "People in the News" note that appeared in the October 1984 issue. 


\section{A quality science library without the Science Citation Index $x^{\circledast}$}
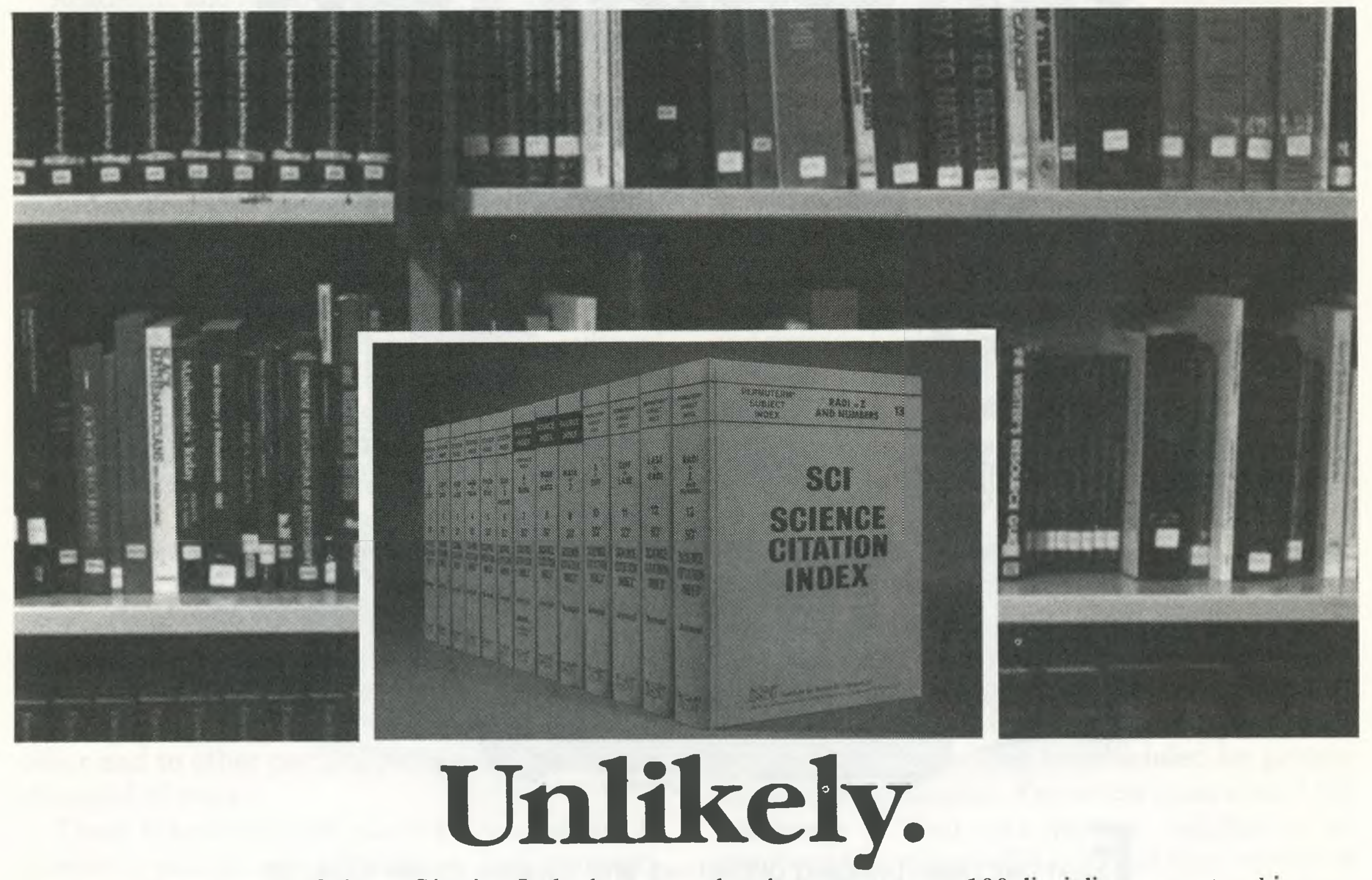

For over 20 years, the Science Citation Index has $\boldsymbol{F}_{\text {been an integral part of science reference }}$ collections. Why? Because the $S C I{ }^{\circledR}$ gives you access to the world's most significant scientific and technical literature. Because it offers unmatched breadth of coverage, depth of indexing, and precision of retrieval. And because the SCI's cumulated editions make it easy to search back to 1955 .

If you've used the Science Citation Index, you know it's more than a valuable search tool. You know it's also an important tool for performing bibliographic verification . . . following scientific development across 100 disciplines . . . tracking faculty publishing . . . and determining who's citing whom.

Your subscription to the Science Citation Index gives you all of this . . . plus it qualifies you for reduced rates on $S C I S E A R C H^{\circledR}$, the online version of $S C I$.

And the Science Citation Index is available at special grant rates to libraries that qualify.

To find out more about the Science Citation Index and its place in your library-or for information on ISI's Grant Program-write or call us at the address below.

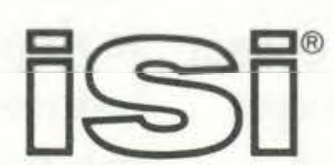

\section{Institute for Scientific Information \\ Customer Services}

3501 Market Street, Philadelphia, PA 19104 U.S.A., Telephone: (215) 386-0100, Ext.1371, Cable:SCINFO, Telex: 84-5305 European Office: 132 High Street, Uxbridge, Middlesex UB8 1DP, United Kingdom

Phone: 44-895-70016, Telex: 933693 UKISI 


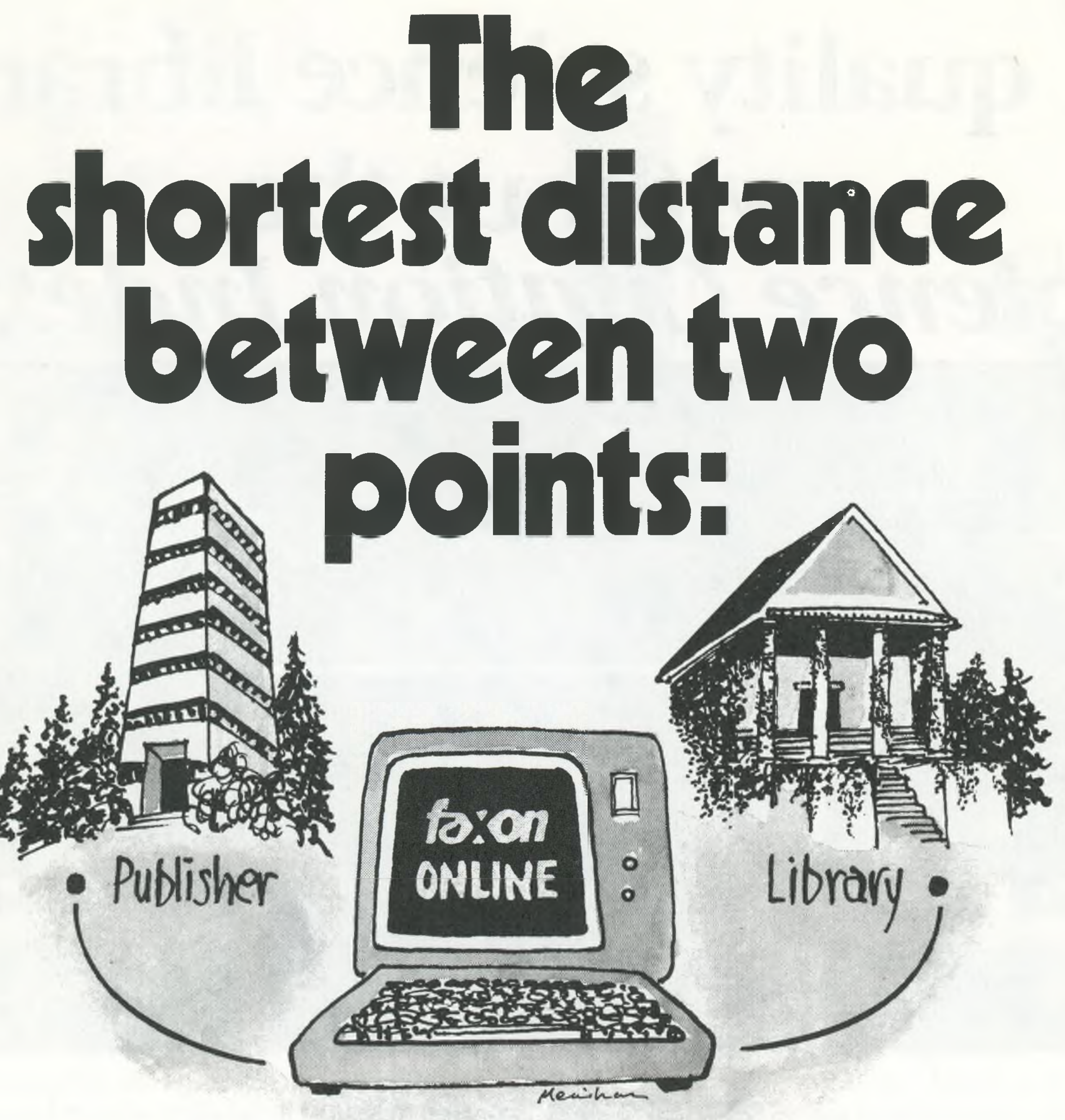

F

axon has been bringing publishers and libraries closer together for more than 100 years. Today our online links facilitate an information exchange that affords you current, accurate subscription management.

Our latest online services are PUBLINX and INFOSERV. PUBLINX provides publishers with the power to access and update information on their serial titles, and to receive claims and orders online. With INFOSERV, libraries can search for new titles, request additional information and sample copies, and order subscriptions.

Our electronic edge is making the distance between library and publisher shorter every day. And we're only a phone call away.

$800225-6055$ or $617329-3350$ collect

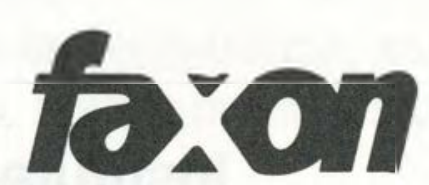

ON THE FRONTIER OF INFORMATION MANAGEMENT

The Faxon Company, Inc. 15 Southwest Park Westwood, MA 02090 
Kathman and Virgil F. Massman, eds., Options for the 80s: Proceedings of the Second National Conference of the Association of College and Research
Libraries (Greenwich, Ct.: JAI Press, 1982), pp. 413-19.

\section{"Energies for Transition" to be theme of ACRL's Fourth National Conference in Baltimore, April 9-12, 1986.}

Academic and research libraries, the institutions of which they are a part, the environments in which they function, and the constituencies they serve, are all swept up in transitions of numerous kinds and dimensions.

Trends in higher education, including changes in instruction and research focus, and in institutional relationships to government, business, and industry, all place new demands on libraries. Demographic shifts created by population movement and differing mixes of socio-economic-cultural groups, the birth rate, fluctuations in the economy, the rise of the information society-all affect institutional goals.

Library management techniques are changing in order to accomodate both austerity and affluence, unionization, and emerging organizational structures. Campuses are being wired to utilize new technologies for data and video transmission and to permit necessary telecommunication linkages. Automation continues to find new applications, altering libraries in their relations to each other and to other parts of society in hitherto undreamed of ways.

These transitions are placing demands on libraries to assume new attitudes, to seek appropriate methods, and to exploit finite resources to cope with ever-changing developments. The focus of the 1986 ACRL National Conference in Baltimore will be to explore the theme, "Energies for Transition." The Conference aims to identify the nature of the transitions facing librarians and to suggest energies to meet them, both through the informal gathering of colleagues and formal programs.

Contributed papers are a major feature of the conference, and are invited in any of the following three categories:

1) Research reports are to be descriptions of studies which utilize rigorous research methodology and which include identified hypotheses and clearly stated conclusions. The maximum length of each report should be 2,500 words to be presented within 20 minutes; a 10-minute question and answer period will be scheduled for each research report.

2) Position papers are to be presentations in which problems are clearly identified and solutions proposed. Descriptions may be of locally implemented experiences (successes and failures), theoretical models, or state of the art reviews. Although not requiring formal research methodology, these papers should be well organized, and should develop clear positions or concepts. The maximum length of each should be 1,800 words and each presentation should be no more than 15 minutes, followed by 15 minutes for comments and reactions from the audience.

3) Idea briefs are to be short introductions of possible research ideas, evolving concepts or programmatic concerns which are intended to stimulate discussion. Each brief should clearly state the topic and provide background within a maximum of 500 words and should be presented within 10 minutes, followed by a 20 minute discussion.

Each research report and position paper will be reviewed by at least two referees as part of the selection process. Idea briefs will be considered by the Contributed Papers Committee. Criteria for selection include clarity, originality, relevance to the theme, and suitability for oral presentation.

Accepted papers may be returned to the authors for final editing and preparation of camera-ready copy to be included in the published conference proceedings. Papers may be scheduled for presentation more than once. Presenters must attend the conference at their own expense. Additional instructions to authors will be mailed upon receipt of the Notice of Intention to Submit a Paper or Brief.

Schedule for submission:

March 1, 1985-Notice of Intention to Submit a Paper or Brief due.

May 15, 1985-Submitted manuscript due.

October 15, 1985-Notification of acceptance sent.

November 15, 1985-Camera-ready copy of accepted papers due.

Potential contributors are urged to send a notice of Intention to Submit a Paper or Brief. It should include the following:

1) Name and mailing address.

2) Work and home phone numbers.

3) Category of contribution (select one: research report, position paper, or idea brief).

4) Tentative paper title.

5) A brief (no more than 200 words) description of the proposed paper.

Send the Notice of Intention no later than March 1, 1985, to ACRL Contributed Papers, c/o Danuta A. Nitecki, Office of Public Services, McKeldin Library 2124, University of Maryland, College Park, MD 20742. 


\section{B.C. library inspires epic poem}

The only university library in British Columbia's rugged interior reopened November 28 thanks to concerted efforts by students, faculty, and friends of the school, which had closed at the end of Spring Semester.

The David Thompson University Centre Library (DTUC), Nelson, B.C., was occupied by concerned city residents last April after the provincial government's announcement that it could no longer keep the school funded. The townspeople intended to prevent the breaking up of the library's collection, much of which had been donated by local citizens. The occupiers felt that the library would be a crucial factor in the re-establishment of any future academic institution.

The sit-in lasted until July when an agreement was reached between the B.C. Ministry of Education and the Nelson City Council that allowed the library to be opened to the public if the city would pay maintenance costs. The library, staffed by volunteers, is now open 20 hours a week.

The whole story of the occupiers and their eventual triumph has been told in a delightful 19-page monograph by retired government employee Sam Dodds. Called The Sedentary Tales, the saga is written in Chaucerian heroic couplets accompanied by medieval-looking calligraphy and illustrations. The poet likens the seven original occupiers to the Canterbury pilgrims who sought lodging at an inn (the library) and told their tales to the innkeeper (the chief librarian).

Here is an excerpt from "The Educator's Tale":

"The University hath closed its doors, and very Soon-as ye have said-will shutter its library. And what with all such careless breach of faith As has transpired, you'll understand how laith Are we to twiddle thumbs and stand aside While others quietly sort out and scatter wide The books and artifacts this campus had in storeAnd, with them, all our hopes that Deetuc may arise once more!...

Here, for all the civil style in which we greet you, You see six specimens of homo disobediens in situ."

Copies of this stirring narrative are available for $\$ 3$, payable to the DTUC Support Society, from Sam Dodds, Box 200, Nelson, BC, Canada V1L 5P9. All proceeds beyond the cost of printing will be donated to the cause of arts and humanities education in Nelson.

\section{ALA Publishing Services offers aid to bibliographers}

James Lyman Whitney, chief of the Department of Statistics and Manuscripts of the Boston Public Library, was a charter member of ALA and served as treasurer from 1882 to 1886 . When he died in 1910 , he left a bequest for the purpose of assisting in the preparation of bibliographic aids. In 1983 this fund was combined with the Carnegie Reading List Awards fund (established by Andrew Carnegie in 1902) for which official units of ALA are eligible. The name of the awards was changed to the Whitney-Carnegie Awards. They are administered by the ALA Publishing Committee.

Eligibility: The Whitney-Carnegie Awards are available to individuals.

Criteria: In April 1982 the ALA Executive Board determined that grants would be made "for the preparation of bibliographical aids for research. The aids must be aimed at a scholarly audience but have a general applicability." The awards may cover any costs appropriate to the preparation of a useful product and are ordinarily for no more than $\$ 2,500$.

Applications: Grants are made from the com- bined income of the two funds. Applications from individuals should clearly designate that they are intended for the Whitney-Carnegie Award and must contain the following items:

-Statement of purpose, to include a description of the project and its intended audience.

-Plan of work, to include a schedule for completion.

- Budget, to include a clear justification for travel if funds for this purpose are requested.

- Publication plans if a commitment has already been made. Preference may be given to projects for which ALA may serve as a publisher.

The ALA Publishing Committee reviews the proposals and recommends to the ALA Executive Board both recipients and the amounts of their awards. Proposals should be submitted to the Chair, ALA Publishing Committee, 50 E. Huron Street, Chicago, IL 60611; (312) 944-6780.

Proposals must be submitted no later than February 28 for consideration at the following meeting of the Publishing Committee (usually in April). 